\title{
Impact of Galvanic Anode Dissolution on Metal Trace Element Concentrations in Marine Waters
}

\author{
Deborde Jonathan ${ }^{1,{ }^{*}}$, Refait Philippe ${ }^{2}$, Bustamante Paco ${ }^{3}$, Caplat Christelle ${ }^{4}$, Basuyaux Olivier ${ }^{5}$, \\ Grolleau Anne-Marie ${ }^{6}$, Mahaut Marie-Laure ${ }^{7}$, Brach-Papa Christophe ${ }^{8}$, Gonzalez Jean-Louis ${ }^{9}$, \\ Pineau Samuel ${ }^{1}$
}

${ }^{1}$ ACCOAST, Espace Atlantis, F-56610 Arradon, France.

2 Univ La Rochelle, UMR CNRS 7356, Lab Sci Ingn Environm LaSIE, F-17042 La Rochelle 01, France.

3 Univ La Rochelle, UMR CNRS 7266, Littoral Environm \& Soc LIENSs, F-17000 La Rochelle, France.

4 Normandie Univ, UPMC, MNHN,UCBN,IRD 207, Biol ORganismes \& Ecosyst Aquat,UMR BOREA

CNRS 72, F-50130 Octeville, France.

5 SMEL, Ctr Expt, ZAC Blainville, F-50560 Blainville Sur Mer, France.

${ }^{6}$ DCNS Res, F-50104 Octeville, France.

7 CNAM INTECHMER, F-50103 Cherbourg, France.

8 IFREMER, Ctr Atlantique, Unite Biogeochim \& Ecotoxicol, F-44311 Nantes 03, France.

9 IFREMER, Ctr Mediterranee, Lab Biogeochim Contaminants Metall, F-83507 La Seyne Sur Mer, France.

${ }^{*}$ Corresponding author : Jonathan Deborde, email address : jonathan.deborde@gmail.com

\begin{abstract}
:
Submerged harbor steel structures often employ cathodic protection using galvanic anodes to guard against corrosion. A laboratory experiment, with three different cathodic protection configurations by galvanic aluminum-based anodes, was performed to evaluate the potential metal transfer from the anodic alloy dissolution into the surrounding marine water. The anode dissolution rate is proportional to the imposed current demands and induced a significant $\mathrm{Al}, \mathrm{In}$, and $\mathrm{Zn}$ transfer in the dissolved and particulate fractions of the corrosion product layers covering the anode surface. These layers were poorly adherent, even under low hydrodynamic conditions. Consequently, at the anode vicinity, the suspended particle matter and dissolved fraction of surrounding marine waters showed strong enrichments in $\mathrm{Al}$ and $\mathrm{Zn}$, respectively, the values of which could potentially affect the adjacent biota. After the anode activation period, however, the metal inputs from galvanic anode dissolution are rapidly diluted by seawater renewal. At regional scale, these metal fluxes should be negligible compared to river and wastewater fluxes. These results also showed that it is difficult to assess the impact of the anode dissolution on the concentrations of metals in the natural environment, especially for metals included in trace amounts in the anode alloy (i.e., $\mathrm{Cu}, \mathrm{Fe}, \mathrm{In}, \mathrm{Mn}$, and $\mathrm{Si}$ ) in the aquatic compartment.
\end{abstract}

Keywords : Galvanic anode, Aluminum, Zinc, Metal transfer, Seawater 


\section{Introduction}

Harbor steel structures that are exposed to seawater or buried in marine sediments often employ cathodic protection to prevent corrosion. The aim is to bring the surface of the immersed structures to a lower potential (cathode), where the metal oxidation is significantly slowed down and the oxidant species reduction is accelerated in order to ensure satisfactory corrosion kinetics for the whole metal surface. Cathodic protection can be applied using two methods: by impressed current or by the deployment of galvanic metal anodes on the infrastructure. Protection by galvanic anodes is more generally used in harbors (boats and structures) and has been applied since the early 1960s (Bird et al. 1996; Roy 1968; Shibli and Gireesh 2005) leading to the release of large amounts of metals that composed the anodes into the harbor environments.

Different metals, such as $\mathrm{Al}, \mathrm{Zn}$, or $\mathrm{Mg}$, are used as the main components of galvanic anodes. Al-based galvanic anodes are predominantly used in cathodic protection of harbor steel structures because of their higher efficiency, low density, large electrochemical equivalent, availability, and reasonable cost (Shibli et al. 2008). Pure Al is not suitable for galvanic anodes due to the formation of a passive oxide film on its surface, which induces a relatively noble potential in seawater. To promote activation and to improve the electrochemical and structural properties of $\mathrm{Al}$ anodes, several metals, such as $\mathrm{Ga}, \mathrm{Hg}$, In, or $\mathrm{Sn}$, are added in low quantities in the alloy (Breslin and Carroll 1993; Carroll and Breslin 1992; Idusuyi and Oluwole 2012; Saidman and Bessone 1997). The cathodic protection by galvanic anodes involves the progressive alloy dissolution and consequent release of the metals included in the anode alloy into the marine environment. Metals may be released as dissolved species or as particles of solid phase. Once released, these metals could diffuse and contaminate surrounding waters or may be accumulated in the suspended particle matter (SPM), sediments, and biota (Caplat et al. 2010; Gabelle et al. 2012; Leleyter et al. 2007; Mao et al. 2011; Mottin et al. 2012; Rousseau et al. 2009).

The load of Al galvanic anodes used on harbor structures is important and can reach a few hundred tons in commercial ports, and the alloys will oxidize over several years (Wagner et al. 1996). Harbors can be confined or semi-enclosed zones with low depth and low seawater renewal by tide or current. These specific conditions induce a high turbidity and biologic productivity. Consequently, metal inputs from anode dissolution could be significant in these environments, causing potential ecological damage (Jelmert et al. 2000; Mao et al. 2011). However, the fate of metals from anode dissolution in the marine environment is not well characterized and has been poorly studied (Bird et al. 1996; Caplat et al. 2010; Gabelle et al. 2012; Leleyter et al. 2007; Mao et al. 2011; Mottin et al. 2012; Rousseau et al. 2009). 
In order to assess the metal transfers to marine environment during $\mathrm{Al}$ galvanic anode dissolution, a laboratory experiment was conducted over 4 months with natural seawater and three different cathodic protection layouts. Due to the lack of information about transfers and the speciation of metals from anodes in the open scientific literature, the present study first focused on the transfer of the oxidation products from the anode surface to the aquatic compartment. We used direct water analyses (total and dissolved fractions) and diffusive gradient on thin film (DGT) devices (dissolved labile fraction) to provide instantaneous and integrative values of metal concentrations over the duration of the experiment. Metal analyses were also carried out in the degradation layers on the anodes and on the sedimented degradation products to assess the evolution of the anode composition at different stages of its degradation. These preliminary and innovative results are presented in this work.

\section{Materials and methods}

\subsection{Experimental design}

A laboratory experiment was conducted for 130 days in four tanks (60 L) without a sediment layer at the bottom. The tanks were supplied with decanted natural seawater pumped from the Cherbourg harbor and contained SPM $\left(6.0 \pm 2.0 \mathrm{mg} \mathrm{L}^{-1}\right.$, Fig. 1). The physicochemical parameters of seawater, temperature, $\mathrm{pH}$, salinity, conductivity, and dissolved $\mathrm{O}_{2}$ concentration were measured in the tanks two times per week. The seawater temperature changed with the seasons from 14.7 to 18.9 ${ }^{\circ} \mathrm{C}$, the average $\mathrm{pH}$ was $7.6 \pm 0.4$, average salinity was $34.5 \pm 0.2$, and average conductivity was $44 \pm 2$ $\mathrm{mS} \mathrm{cm}{ }^{-1}$. In each experimental tank, a continuous seawater renewal of $120 \mathrm{~L} \mathrm{~h}^{-1}$ and low circulation were maintained, which allowed a dissolved oxygen concentration between 5.4 and $8.0 \mathrm{mg} \mathrm{L}^{-1}$. Three cathodic protection layouts were implemented in each tank:

- 1. A tank with a steel/anode combination (S/A T): the steel sample was proportioned to allow the coupled galvanic anode to discharge an average current of about $70 \pm 20 \mathrm{~mA}$;

- 2. A tank with two galvanic anodes connected to a galvanostat at $100 \mathrm{~mA}$ current discharge (100 T);

- 3. A tank with two galvanic anodes connected to a galvanostat at $200 \mathrm{~mA}$ current discharge during 60 days then at $100 \mathrm{~mA}$ current discharge during the 70 last days (200/100 T).

The five galvanic anodes (Bera15) were provided by BAC® and corresponded to an Al-Zn-In alloy, including In, Fe, Si, $\mathrm{Cu}$ and $\mathrm{Mn}$ (composition 2.5-6.5 \% Zn; <0.1\% Si; <0.09 \% Fe; 0.01$0.03 \% \mathrm{In} ;<0.006 \% \mathrm{Cu} ;<0.01 \% \mathrm{Mn}$; and the balance in $\mathrm{Al}$ ). This anode alloy, commonly called $\mathrm{Al}-\mathrm{Zn}$-In alloy, is the most commonly used in European harbors. The anode weight was about $1670 \pm 70 \mathrm{~g}$ and the anode surface was about $630 \mathrm{~cm}^{2}$ at the beginning of the experiment. Current 
discharge and potential were controlled two times per week. With these configurations, the chemical forms of metal released from the anodes were reproduced as in natural conditions. The fourth experimental tank was without galvanic anode as a reference tank (RT) and was monitored at the same frequency.

\subsection{Sampling strategy}

The experiment included the monitoring of $\mathrm{Al}, \mathrm{Cu}, \mathrm{Fe}, \mathrm{In}, \mathrm{Si}$, and $\mathrm{Zn}$ concentrations in dissolved fraction and the total fraction (dissolved metals $\mathrm{Al}, \mathrm{Cu}, \mathrm{Fe}, \mathrm{In}$, and $\mathrm{Zn}+$ their association to $\mathrm{SPM}$ ) of seawater tanks. Waters were sampled in each tank at $\mathrm{T}_{0}, \mathrm{~T}_{7}, \mathrm{~T}_{14}, \mathrm{~T}_{22}, \mathrm{~T}_{29}, \mathrm{~T}_{60}, \mathrm{~T}_{67}, \mathrm{~T}_{77}, \mathrm{~T}_{88}$, $\mathrm{T}_{95}, \mathrm{~T}_{105}, \mathrm{~T}_{123}$ and $\mathrm{T}_{130}$ during the 130-day experiment. For the total fraction, 500-mL triplicate water samples were collected in polypropylene decontaminated bottles and immediately acidified to $\mathrm{pH} 1.6$ with $65 \%$ suprapur nitric acid before being stored at $4{ }^{\circ} \mathrm{C}$ until chemical analyses were performed. For the dissolved fraction, a $250-\mathrm{mL}$ water sample was filtered with $0.45-\mu \mathrm{m}$ pore size polycarbonate filters (acid cleaned, Nucleopore) and acidified at $0.1 \%$ with $69 \%$ ultrapure nitric acid before being stored in double bagged polyethylene bottles until chemical analysis.

Additionally, the labile fraction of dissolved $\mathrm{Al}, \mathrm{Cu}, \mathrm{Fe}, \mathrm{Mn}$, and $\mathrm{Zn}$ was investigated by DGT samplers (Davison and Zhang 1994; de Souza et al. 2014; Montero et al. 2012; Søndergaard et al. 2014; Warnken et al. 2007; Zhang and Davison 1995). Three DGT devices were deployed in each experimental tank. The devices were immersed in the water for one week at $\mathrm{T}_{0-7}, \mathrm{~T}_{22-29}, \mathrm{~T}_{60-67}, \mathrm{~T}_{88-}$ 95, and $\mathrm{T}_{123-130}$. When retrieved, salinity and temperature were measured, and the immersion time was recorded to the nearest minute. The DGT exposition window was cleaned with deionized water, to remove any particles adhering to the surface, and each device was stored in an individual clean plastic bag. The DGT probes were then refrigerated at $4{ }^{\circ} \mathrm{C}$ until chemical analysis.

The seawater flowing into the four experimental tanks was decanted, but even so it contained SPM. During the experiment, a portion of these SPM continuously settled down at the tank bottom due to the low hydrodynamic conditions and flocculation processes. At the end of the experiment, $50 \mathrm{~mL}$ of these settled particles, rich in anode corrosion products, was sampled in each tank. Simultaneously, $50 \mathrm{~mL}$ of the corrosion product layer covering the anode surface was sampled. The solid fraction and interstitial water of these samples were separated by centrifugation at $4000 \mathrm{rpm}$ for $15 \mathrm{~min}$ at $4{ }^{\circ} \mathrm{C}$. Interstitial water was filtered and immediately acidified to $\mathrm{pH} 1.6$ with $65 \%$ suprapure nitric acid. The solid fraction and interstitial water of these corrosion product layers were stored at $-18^{\circ} \mathrm{C}$ until chemical analysis.

At the end of the experiment, the corrosion product layers still adhering to the anode surface

(Fig. 2) were collected with a polypropylene trowel, and weight was measured before and after these layers were dried by lyophilization. 


\subsection{Analytical procedures}

Total metal concentrations in tank seawaters, interstitial waters, sediments, and anode corrosion product layers were analyzed in triplicate by inductively coupled plasma atomic emission spectrometry (Varian Vista-PRO ICP-AES) and ICP coupled with mass spectrometry (Thermo Scientific XSERIES 2 ICP-MS) as described in Hédouin et al. (2011). For each set of analyses, blanks were included in each analytical batch and were used to calculate the detection limit (three times the standard deviation of eight blanks). The analytical detection limits were $5 \mu \mathrm{g} \mathrm{L}^{-1}$ for each metal in water and $0.5 \mu \mathrm{g} \mathrm{g}^{-1}$ for each metal in solid phase. Dissolved $\mathrm{Al}, \mathrm{Cu}, \mathrm{Fe}, \mathrm{In}, \mathrm{Mn}, \mathrm{Si}$, and $\mathrm{Zn}$ were analyzed in triplicate by liquid/liquid extraction adapted from Danielsson et al. (1982) as described by Chiffoleau et al. (2003) and measured by Q ICP-MS using an external calibration (five to six points) in diluted nitric acid media. Internal standards were systematically added to all solutions to correct for instrumental drift. Quality controls were satisfactorily performed by analyzing seawater certified reference material NASS-6 (National Research Council Canada, Ottawa, Canada), with a precision of $\pm 10 \%$, and the limit of detection was $0.2 \mu \mathrm{g} \mathrm{L}^{-1}$ for each dissolved metal. After the DGT deployment, the Chelex resin of the probes was peeled off in the laboratory and metals were extracted in $1.8 \mathrm{~mL}$ of $1 \mathrm{M}$ ultrapure nitric acid $(24-48 \mathrm{~h})$. Metal concentrations in the acid extracts were analyzed using ICP-MS (detection limit $1 \mu \mathrm{g} \mathrm{L}^{-1}$ for each metal) to determine the mass of metal accumulated in the Chelex 100 resin (M). Then, the average labile metal concentrations in water (CDGT) were calculated using the following equation (Montero et al. 2012; Zhang and Davison 1995):

$$
\mathrm{C}_{\mathrm{DGT}}=(\mathrm{M} \cdot \Delta \mathrm{g}) /(\mathrm{Dm} \cdot \mathrm{t} \cdot \mathrm{A})
$$

where $\mathrm{M}$ is the mass of metal accumulated in the resin, $\Delta \mathrm{g}$ is the diffusive layer thickness, $\mathrm{Dm}$ is the diffusion coefficient of the metal, $\mathrm{t}$ is the immersion time of the DGT probe, and A is the exposure area. Diffusion coefficients for the average water temperatures over the deployment period as provided by DGT Research were used.

\section{Results}

\subsection{Anode dissolution and corrosion product layer formation}

From the first days of anode activation and in all of the experimental configurations, corrosion products constituted a loose, poorly adherent white layer on the anode surface (Fig. 2). In some cases, the thickness of this layer reached $1 \mathrm{~cm}$ after only 2 weeks. These products formed continuously during the whole life of the galvanic anode without apparent (visual) changes. Even in the low hydrodynamic conditions considered here, according to our mass estimations, an important 
proportion of these corrosion products $(80 \%)$ was transferred to the environment. The corrosion layers were highly hydrated. Weight measurements revealed that the water content of these layers was about $70 \%$.

The dissolution process corresponded to a weight loss of galvanic anodes proportional to the current discharge, ranging between $1.1 \mathrm{mg} \mathrm{cm}^{-2} \mathrm{day}^{-1}$ for S/A T and $2.5 \mathrm{mg} \mathrm{cm}^{-2}$ day $^{-1}$ for 200/100 $\mathrm{T}$ (Table 1). The electrochemical monitoring showed that the corrosion product layers, whatever their thickness, did not interfere with the potential and current discharge of the anodes.

\subsection{Metal concentrations in tank seawaters}

Total concentrations of $\mathrm{Al}, \mathrm{Zn}$, and Fe measured in the tank seawaters are reported in Fig. 3. As seawater was continuously renewed between the first day of anode activation $\left(\mathrm{T}_{0}\right)$ and the last day of the experiment $\left(\mathrm{T}_{130}\right)$, pumped from the Cherbourg harbor, a wide range of values were

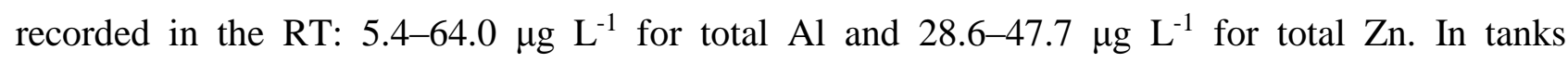
containing galvanic anodes, concentrations of total $\mathrm{Al}$ ranged from $33.0 \mu \mathrm{g} \mathrm{L}^{-1}$ ( $\left.\mathrm{T}_{105}\right)$ to $858 \mu \mathrm{g} \mathrm{L}^{-1}$ ( $\mathrm{T}_{7}$ ) in S/A T, from $68.8 \mu \mathrm{g} \mathrm{L}^{-1}\left(\mathrm{~T}_{113}\right)$ to $1523 \mu \mathrm{g} \mathrm{L}^{-1}\left(\mathrm{~T}_{7}\right)$ in $100 \mathrm{~T}$, and from $139 \mu \mathrm{g} \mathrm{L}^{-1}$ ( $\mathrm{T}_{130}$ ) to $7280 \mu \mathrm{g} \mathrm{L}^{-1}\left(\mathrm{~T}_{7}\right)$ in 200/100 T. Concentrations of total $\mathrm{Zn}$ ranged from $28.3 \mu \mathrm{g} \mathrm{L}^{-1}$ (T0) to $69.6 \mu \mathrm{g}$ $\mathrm{L}^{-1}\left(\mathrm{~T}_{77}\right)$ in $\mathrm{S} / \mathrm{A} \mathrm{T}$, from $33.0 \mu \mathrm{g} \mathrm{L}^{-1}\left(\mathrm{~T}_{113}\right)$ to $153 \mu \mathrm{g} \mathrm{L}^{-1}\left(\mathrm{~T}_{61}\right)$ in $100 \mathrm{~T}$, and from $41.1 \mu \mathrm{g} \mathrm{L}^{-1}$ ( $\left.\mathrm{T}_{0}\right)$ to $360.0 \mu \mathrm{g} \mathrm{L}^{-1}\left(\mathrm{~T}_{7}\right)$ in 200/100 $\mathrm{T}$. Higher values of total $\mathrm{Al}$ and total $\mathrm{Zn}$ were recorded in the first half of the experiment $\left(\mathrm{T}_{0-68}\right)$ and were proportional on the current discharge imposed to the galvanic anode (Table 1). The concentration of total Fe measured in S/A T, 100 T, and 200/100 T (11.4-84.9 $\mu \mathrm{g} \mathrm{\textrm {L } ^ { - 1 }}$ for total $\mathrm{Fe}$ ) were closed and presented the same profiles to those recorded in the RT (12.1$\left.57.7 \mu \mathrm{g} \mathrm{L}^{-1}\right)$, except at the end of experiment $\left(\mathrm{T}_{113-130}\right)$ where a slight increase of concentrations was noted. Total concentrations of In and $\mathrm{Cu}$ measured in the four tanks were below the limit of detection throughout the duration of the experiment (data not shown).

In the dissolved fraction filtered at $0.45 \mu \mathrm{m}$, In concentrations were below the limit of detection in the four experimental tanks throughout the duration of the experiment (data not shown). Concentrations of dissolved $\mathrm{Al}$ and Fe remained stable and similar to those measured in the RT during the experiment (0.2-0.5 $\mu \mathrm{g} \mathrm{L}^{-1}$, data not shown). Concentrations of dissolved $\mathrm{Zn}$ measured in the RT ranged from $35.4 \mu \mathrm{g} \mathrm{L}^{-1}\left(\mathrm{~T}_{7}\right)$ to $66.3 \mu \mathrm{g} \mathrm{L}^{-1}$ (T68), (Fig. 4a). Seawaters of S/AT, $100 \mathrm{~T}$, and 200/100 T showed higher concentrations of dissolved Zn concentrations at the beginning of the experiment ( $\left.\mathrm{T}_{0-29}\right)$, proportional to the current discharge of anodes, which then decreased close to reference values until the end of experiment, except at $\mathrm{T}_{29}$ for $100 \mathrm{~T}$. Concentrations of dissolved $\mathrm{Cu}$ and $\mathrm{Si}$ were similar in S/A T, $100 \mathrm{~T}$, and 200/100 T to those recorded in the RT, from $0.3 \mu \mathrm{g} \mathrm{L}^{-1}$ ( $\left.\mathrm{T}_{7}\right)$ to $0.9 \mu \mathrm{g} \mathrm{L}^{-1}\left(\mathrm{~T}_{68}\right)$ for $\mathrm{Cu}$ and from $52.3\left(\mathrm{~T}_{22}\right)$ to $302.0 \mu \mathrm{g} \mathrm{L}^{-1}\left(\mathrm{~T}_{95}\right)$ for $\mathrm{Si}$ (data not shown). 
The labile $\mathrm{Al}$ and $\mathrm{Zn}$ concentrations measured using DGTs in the four experimental tanks are represented in Fig. 4b, c. Some technical difficulties arose in the analysis of $\mathrm{Al}_{\mathrm{DGT}}$ and induced the loss of some samples, but results showed that labile Al concentrations were higher in the tanks impacted by anode dissolution (range $1.3-12.8 \mu \mathrm{g} \mathrm{L}^{-1}$ ) than in the RT (range $0.2-0.9 \mu \mathrm{g} \mathrm{L}^{-1}$ ), especially in 200/100 T. $\mathrm{Zn}_{\text {DGT }}$, Cud $\mathrm{U}_{\mathrm{DG}}$, Fe $\mathrm{P}_{\mathrm{DGT}}$, and $\mathrm{Mn}_{\text {DGT }}$ concentrations were close within the four experimental tanks and ranged between 4.4 and $12.1 \mu \mathrm{g} \mathrm{L}^{-1}, 0.2$ and $0.4 \mu \mathrm{g} \mathrm{L}^{-1}, 3.7$ and $7.6 \mu \mathrm{g} \mathrm{L}^{-1}$, and 0.7 and $1.7 \mu \mathrm{g} \mathrm{L}^{-1}$, respectively (data not shown for $\mathrm{Cu}_{\mathrm{DGT}}, \mathrm{Fe}_{\mathrm{DGT}}$, and $\mathrm{Mn}_{\mathrm{DGT}}$ ).

\subsection{Metal concentrations in the corrosion product layers and tank sediments}

Table 2 shows the average concentrations of $\mathrm{Al}, \mathrm{In}$, and $\mathrm{Zn}$ recorded at the end of experiment in the liquid and solid fractions of the corrosion product layers and in the sludge settled at the bottom of the tanks. The solid fraction of the corrosion product layers is characterized by very high values of $\mathrm{Al}$ concentration, i.e., $155-159 \mathrm{mg} \mathrm{g}^{-1}$, and low values of $\mathrm{Zn}$ concentration, i.e., 0.3-0.4 $\mathrm{mg} \mathrm{g}^{-1}$. Consequently, the $\mathrm{A} 1 / \mathrm{Zn}$ mass ratio is about 450 in the solid corrosion products, whereas it is about 19 in the anode alloy. In contrast, the $\mathrm{Zn}$ concentration is rather high in the liquid fraction

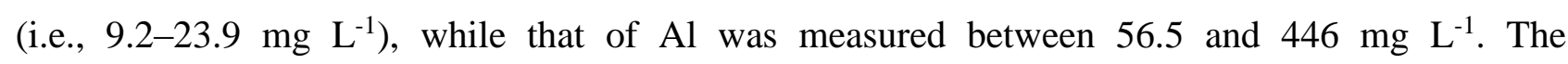
concentrations of In ranged from 41.3 to $74.8 \mu \mathrm{g} \mathrm{g}^{-1}$ in the solid fraction. The $\mathrm{Al} / \mathrm{In}$ mass ratio is then about 2600 in the solid fraction of the corrosion product layers, whereas it is about 4750 in the anode alloy. The solid corrosion products are thus slightly enriched in In. However, these results showed that the solid fraction of the corrosion product layer consists mainly of an aluminum compound, which contains less than 0.26 wt.\% $\mathrm{Zn}$ and less than 0.05 wt.\% In (i.e., approximately 99.7 wt.\% Al).

In tank sediments of S/AT, $100 \mathrm{~T}$, and 200/100 T, the concentrations in the solid fraction ranged from 82.2 to $116 \mathrm{mg} \mathrm{g}^{-1}$ for $\mathrm{Al}$, from 0.5 to $1.0 \mathrm{mg} \mathrm{g}^{-1}$ for $\mathrm{Zn}$, and from 17.2 to $28.7 \mu \mathrm{g} \mathrm{g}^{-1}$ for In, whereas in the RT, the concentrations were $7.8 \mathrm{mg} \mathrm{g}^{-1}$ for $\mathrm{Al}, 0.7 \mathrm{mg} \mathrm{g}^{-1}$ for $\mathrm{Zn}$, and below the detection limit for In. The interstitial waters showed high values of $\mathrm{Al}$ and $\mathrm{Zn}$ in the impacted experimental tanks, especially in $100 \mathrm{~T}$ and 200/100 T. In concentrations remained below the detection limit in all interstitial water samples, such as $\mathrm{Cu}, \mathrm{Fe}$, and $\mathrm{Mn}$ concentrations (data not showed). Once again, the solid fraction is characterized by an $\mathrm{Al} / \mathrm{Zn}$ ratio much higher than that of the anode alloy.

\section{Discussion}

\subsection{Al galvanic anode dissolution and theoretical metal inputs to marine waters}

Current demands of $70 \pm 20 \mathrm{~mA}$ in S/A T, $100 \pm 10 \mathrm{~mA}$ in $100 \mathrm{~T}$, and $200 \pm 20 \mathrm{~mA}$ (during 60 days) then $100 \pm 10 \mathrm{~mA}$ (during the last 70 days) in 200/100 $\mathrm{T}$ were imposed on the anodes in order 
to simulate a large range of possible current demands by harbor structures under cathodic protection (Table 1). These current demands induced proportional anode dissolution rates between 1.1 (for S/A T) and $2.5 \mathrm{mg} \mathrm{cm}^{-2} \mathrm{day}^{-1}(200 / 100 \mathrm{~T})$, releasing metals from the anode as dissolved species and solid particles in the aquatic environment. Based on metal abundance in the anode alloy, these rates represented daily $\mathrm{Al}$ and $\mathrm{Zn}$ inputs to the aquatic environment from the anode composed of between 979 (S/A T) and $2340 \mu \mathrm{g} \mathrm{cm}^{-2}$ day $^{-1}(200 / 100 \mathrm{~T})$ and between 68.3 (S/A T) and $163.1 \mu \mathrm{g} \mathrm{cm}^{-2}$ day $^{-1}$ (200/100 T), respectively (Table 3). A harbor with an average freight (about $40 \mathrm{Mt} \mathrm{year}^{-1}$ ) can use approximately $560 \mathrm{t}$ of galvanic anodes for the cathodic protection of its immersed structures over the course of 20 years (pers. com.). According to our experimental results, this anode load and surface should correspond to 35 to $85 \mathrm{~kg}$ year $^{-1}$ of $\mathrm{Al}$ and 2.5 to $5.9 \mathrm{~kg}_{\text {year }}{ }^{-1}$ of $\mathrm{Zn}$ directly transferred to the marine environment by the dissolution of galvanic anodes. These rough estimations of metal transfers to the marine environment suggest that this method could have a significant impact on water and sediment quality at local scale, especially in the confined zones of the harbor.

However, our experimental anode dissolution rates seemed to be slightly higher than those observed in harbor environments (below $0.9 \mathrm{mg} \mathrm{cm}^{-2}$ day $^{-1}$ ) and those recommended by European standards (NF-EN-12473 2014; NF-EN-12495 2000; NF-EN-12496 and NF-EN-ISO-13174 2013, inducing overestimated values. Second, our previous work has shown that the anode dissolution rates are not steady throughout the galvanic anode life. Anode dissolution rates are maximal during the first weeks of anode activation, corresponding to the polarization time of immersed steel structures, and rapidly decrease after a few weeks (Paugam et al. 2014). Finally, numerous works demonstrate that rivers or urban wastewaters export large amounts of $\mathrm{Al}$ and $\mathrm{Zn}$. For example, one of the major French rivers export between 205 and $420 \mathrm{t}_{\text {year }}^{-1}$ of $\mathrm{Al}$ and between 38 and $130 \mathrm{t}^{\mathrm{t}}$ year ${ }^{1}$ of Zn (Buzier et al. 2011; Chiffoleau et al. 1999; Michel et al. 2000; Thévenot et al. 2007); treated effluents from industrial areas could export more than $91 \mathrm{t}^{\text {year }}{ }^{-1}$ of $\mathrm{Al}$ and between 1 and $687 \mathrm{~kg}$ year $^{-1}$ of Zn (Buzier et al. 2006; Martínez-Santos et al. 2015; Paraskevas et al. 2015). Compared to these continental inputs, the metal transfers from galvanic anode dissolution at regional scale are negligible and difficult to assess.

\subsection{Fate of anode corrosion products}

Some of the corrosion/dissolution products directly precipitated on the anode surface and created a very loose and porous, poorly adherent, and highly hydrated layer (Fig. 2). Indeed, at pH 8.0 \pm 0.5 , when $\mathrm{Al}$ and $\mathrm{Zn}$ ions exceed 0.38 and $1.16 \mathrm{mg} \mathrm{L}^{-1}$ in seawater, they can precipitate as $\mathrm{Al}(\mathrm{OH})_{3}$ and $\mathrm{Zn}(\mathrm{OH})_{2}$, respectively (Buck et al. 2013; Jelmert and van Leeuwen 2000; Tria et al. 2007). These corrosion product layers did not constitute a physical barrier able to hinder the 
dissolution of the anode and, whatever their thicknesses, did not interfere with potential and current discharge of the anodes. The solid phase covering the anode surface seemed to be mainly constituted of an $\mathrm{Al}$ compound, with a slight In enrichment compared to the alloy (0.05 vs $0.03 \%$, Table 2). In contrast, the interstitial water contained high concentrations of both dissolved $\mathrm{Al}$ and Zn species, which were 1000 times higher than the values measured in the RT, supplied by natural seawater pumped from the Cherbourg harbor. Even if other metals remained below the detection limits, due to their trace concentrations in the anode alloy and/or because of their affinity to the solid phase in seawater, the corrosion product layer as a whole (i.e., solid and liquid fraction) constitutes a very mobile pool highly enriched in anode metals. These metals constitute an important source for the adjacent aquatic environment.

In harbors, the removal of the corrosion product layer from the anode surface is favored by the tide and currents or organisms that can tear out fragments of the layer. Under the low hydrodynamic conditions of our experiment, a significant proportion of the solid corrosion products (>80\%) was still transferred toward the marine environment. The solid corrosion products are continuously liberated, and the heaviest particles settled at the anode vicinity due to gravity (Fig. 2). The chemical analysis on the settled tank sediments and its interstitial waters showed a huge enrichment in $\mathrm{Al}, \mathrm{Zn}$, and In at the end of the experiment compared to values measured in the reference sediment tank (Table 2). These values largely exceeded the measured concentrations in superficial marine sediments, even in those impacted by human activities: $10-33 \mathrm{mg} \mathrm{g}^{-1}$ for $\mathrm{Al}, 24-$ $167 \mu \mathrm{g} \mathrm{g}^{-1}$ for $\mathrm{Zn}$, and 2.9 10-3-5.7 $\mathrm{ng} \mathrm{g}^{-1}$ for In (Boughriet et al. 2007; Duan et al. 2010; Gabelle et al. 2012; Santos et al. 2005; Tessier et al. 2014). These results demonstrated that the cathodic protection by galvanic anodes could strongly impact metal concentrations in the solid fraction. However, our experiment was conducted without marine sediment layers in the tanks, which induced higher metal proportions in very confined mesocosms. Consequently, at a real interface of harbor sediments, due to local hydrodynamics and sedimentation rate, the solid corrosion products formed during cathodic protection should induce only local (close to the anode) and temporary contamination after an erosion episode. Indeed, a previous study showed that anodic dissolution induced a significant metal enrichment of superficial sediments sampled only from undredged areas and were limited to the immediate vicinity $(<20 \mathrm{~m})$ of the $\mathrm{Al}$ anodes (Gabelle et al. 2012).

\subsection{Metal concentrations in seawater}

A portion of the transferred corrosion products remains in the water column, associated to the SPM or as dissolved fraction. This diffuse input of metals into seawater is difficult to assess in natural conditions due to the dilution effect specific to each considered harbor. In the experimental tanks, during the first weeks, our results showed that the cathodic protection also induced high $\mathrm{Al}$ 
and $\mathrm{Zn}$ transfer toward seawater (Fig. 3). Total $\mathrm{Al}$ and $\mathrm{Zn}$ seawater concentrations reached values about 100 times and 10 times, respectively, higher than those measured in the RT or in harbor seawaters under cathodic protection by anodes ( 9 to $70 \mu \mathrm{g} \mathrm{L}^{-1}$ for $\mathrm{Al}$ and 25 to $45 \mu \mathrm{g} \mathrm{L}^{-1}$ for $\mathrm{Zn}$, this study; Bird et al. 1996; Gabelle et al. 2012; Leleyter et al. 2007). For comparison, total concentrations in open ocean are below $10 \mu \mathrm{g} \mathrm{L}^{-1}$ for $\mathrm{Al}$ and $0.5 \mu \mathrm{g} \mathrm{\textrm {L } ^ { - 1 }}$ for $\mathrm{Zn}$ (Alberti et al. 2005; Brown et al. 1989; Ohnemus and Lam 2015).

Dissolved Al concentrations measured by discrete seawater sampling remained close RT values and the limit of detection because $\mathrm{Al}$ is not commonly dissolved in the natural seawater $\mathrm{pH}$ range of 7.8-8.2 (Alberti et al. 2005; Mackin and Aller 1984; van den Berg et al. 1994) and Al inputs from the anodes were mainly present as colloidal and particulate matter above $0.45 \mu \mathrm{m}(>83$ $\%$ of total Al, Fig. 5a). However, our integrative samplings with DGTs permitted us to show that Al in seawater is not only present in particulate or colloidal forms but also dissolved as DGT-labile fraction (Figs. $4 \mathrm{~b}$ and 5a, <12\% of total Al, also as reported by Alberti et al. 2005). Moreover, the cathodic protection seemed to induce an increase of DGT-labile Al fraction, with proportions of 71$96 \%$ of dissolved fraction, as opposed to 32-64\% in the RT (Fig. 5b). On the other hand, the cathodic protection seemed predominantly to increase the dissolved $\mathrm{Zn}$ concentrations (65-100\% of total Zn, Fig. 5c) at the beginning of anode activation, but not to impact the DGT-labile fraction (Fig. 4c), which represented between 7 and $13 \%$ of the dissolved fraction in the four tanks (Fig. 5d). In seawaters, $\mathrm{Zn}$ is mainly present in dissolved forms; natural organic ligands strongly bind $\mathrm{Zn}$ and dominate the speciation of the total Zn pool (95\%, Ellwood and Van den Berg 2000; Kim et al. 2015; Skrabal et al. 2006). This can explain its difference of behavior from Al. A previous experimental study showed that a complete release in the environment of the corrosion product layer of a $\mathrm{Zn}$ anode induced a high water contamination by enhancing the $\mathrm{Zn}$ solid compound dissolution (Rousseau et al. 2009). Nevertheless, these authors also demonstrated that this water contamination was only very limited and then rapidly attenuated (in less than 11 days), which coincide with our results (attenuated after 29 days, Fig. 4a), certainly due to the dilution effect and/or some sorption phenomenon of $\mathrm{Zn}$ into the sediments and SPM (Ellwood and Van den Berg 2000; Jelmert and van Leeuwen 2000).

The few studies about $\mathrm{Al}$ and $\mathrm{Zn}$ seawater contamination impacts on marine organisms have always highlighted a range of sub-lethal effects, including reduced swimming, feeding, growth and reproduction performance, bioaccumulation, and digestive stress (Baker et al. 2014; Caplat et al. 2010; Mao et al. 2011; Mottin et al. 2012; Nadella et al. 2013; Taylor et al. 1985). Due to these incidences, numerous environmental quality standards for $\mathrm{Al}$ and $\mathrm{Zn}$ in seawaters have been proposed. For examples, for acid soluble $\mathrm{Al}$ at neutral $\mathrm{pH}$, the US EPA established acute and chronic aquatic life criteria of 750 and $87 \mu \mathrm{g} \mathrm{L}^{-1}$, respectively, and the same criteria for $\mathrm{Zn}$ oxides of 
81 and $90 \mu \mathrm{g} \mathrm{L} \mathrm{L}^{-1}$, respectively (Ehrlich 1988; EPA 2009); the OSPAR Convention provisional ecotoxicological assessment criteria for $\mathrm{Zn}$ is $5 \mu \mathrm{g} \mathrm{\textrm {L } ^ { - 1 }}$ (OSPAR 1997). It is important to note that during the first weeks of our experiment, the total $\mathrm{Al}$ and $\mathrm{Zn}$ concentrations measured in the seawater tanks exceeded all of these different water quality standards and at levels which could be potentially toxic for marine organisms.

Other metals that constitute the anode alloy $(\mathrm{Cu}, \mathrm{Fe}, \mathrm{In}$, and $\mathrm{Mn})$ were below the detection limit of the ICP or were close to reference values in labile, dissolved, and total fractions of seawater, even after 130 days of cathodic protection. This was not surprising as these metals are included at traces in anode alloys and since the seawater used in this experiment was continuously renewed during the 130 days. Moreover, the seawater used in the experimental tanks was already contaminated by various human activities; it is difficult to discern the trace metal sources and thus the impact of the galvanic anode dissolution. According to amass balance calculation, estimated with anode weight loss at the end of the experiment and the anode chemical composition, the analytical detection limit in waters $\left(5 \mu \mathrm{g} \mathrm{L}^{-1}\right)$ was higher than the theoretical concentrations of the trace metals ( $\mathrm{In}, \mathrm{Cu}, \mathrm{Fe}, \mathrm{Si}$, and $\mathrm{Mn}$ ) potentially released toward the aquatic compartment during the 130 days (Table 3), computed from the current flowing through the electrode and assuming that the whole current is associated with the anode dissolution.

After 80 days, the $\mathrm{Al}$ and $\mathrm{Zn}$ concentrations in water drastically decreased and reached reference values (RT, Fig. 3) until the end of experiment. This reduction could be explained by the potential dissolution rate decrease after the anode activation period as well as the water renewal that certainly limited the water metal contamination, but also by sorption processes of dissolved forms on SPM and the precipitation phenomenon due to aggregation. In aquatic media, particles tend to aggregate, and the extent of this aggregation is dependent on the surface charge, particle shape and size, and on the $\mathrm{pH}$ of the medium. In seawater, the increasing salinity, and therefore ionic strength, reduces the negativity of the electrophoretic mobility of the particles to promote aggregation (Batley et al. 2013). As a result, sedimentation of colloids and particles could occur in confined zones (Fig. 2). Previous studies also suggested that marine sediments can buffer the contamination with sorption process when the water is contaminated (Bird et al. 1996; Gabelle et al. 2012; Leleyter et al. 2007; Rousseau et al. 2009). Importantly, this process is reversible if the physicochemical properties of the local environment change and marine sediments thus become an indirect metal pollution source for seawater, especially because the main part of the solubilized metals from anodes are scavenged into the labile fractions of sediments (Caplat et al. 2005; Cukrov et al. 2011; Gabelle et al. 2012; Guevara-Riba et al. 2004; Leleyter et al. 2007; Rousseau et al. 2009; Tang et al. 2008). 


\section{Conclusions}

These experimental conditions without sediment and with an important water renewal could simulate the commissioning of galvanic anodes in large seawater volumes and away from marine sediments. The use of galvanic anodes to apply cathodic protection to immerged steel structures seems to induce a significant $\mathrm{Al}$ and $\mathrm{Zn}$ transfer into tank seawaters proportional to the imposed current demands but limited to the first weeks of the experiment. The containment effect due to the use of experimental tanks induced an overestimation of these contamination levels but allowed us to observe these metal fluxes, which could not be measured in the natural environment due to dilution in water bodies.

The results highlight the important role of SPM on the geochemical cycle of released Al from anodes in seawater. For instance, the interstitial water of the corrosion product layers covering the anode's surface was highly enriched in dissolved $\mathrm{Al}$ and $\mathrm{Zn}$, whereas in the tank seawaters, no variations of dissolved $\mathrm{Al}$ concentrations were noted during the whole experiment, with the exception of a little increase in labile fraction. In contrast, the SPM showed a clear enrichment in $\mathrm{Al}$, which could potentially impact the marine biota, especially the filter-feeding organisms living in the most confined zones. After a few weeks, the SPM enriched in Al rapidly decreased, certainly due to dilution by the water renewal, dissolution rate decrease, and precipitation process. For $\mathrm{Zn}$, the anode dissolution seemed to mostly impact the dissolved fraction, but dissolved $\mathrm{Zn}$ concentrations rapidly decreased after a few days. Finally, it is difficult to assess the impact of the anode dissolution on the concentrations of metals included in trace amounts in the alloy $(\mathrm{Cu}, \mathrm{Fe}, \mathrm{In}$, $\mathrm{Mn}$, and $\mathrm{Si}$ ) in the aquatic compartment because the analytical quantification limits are higher than the theoretical maximum concentrations released into the aqueous environment.

Extrapolated to natural conditions, these experimental results thus show that in situ monitoring of the mere dissolved fraction should be irrelevant in anode-impacted waters due to the dilution and sorption processes on SPM. The contribution of anodes to metal concentrations in marine waters appears to be very low, except, perhaps, in very confined areas or over short periods after anode implementation. Compared to metal continental inputs, the estimated fluxes are negligible at a regional scale. However, the corrosion products constitute a very mobile pool of metals, and eroded particles are continuously settled on the superficial sediments by aggregation and precipitation processes. Further, they could participate in a continuous, diffuse metal transfer toward the water column and sediments, especially at the vicinity of the galvanic anodes when they are implemented in peaceful, shallow waters or near sediment over long periods without dredge. Sedimentary metals can be remobilized later into seawater, depending on bioturbation activity or local modifications of the physicochemical parameters (i.e., $\mathrm{pH}$ or redox conditions changes, Atkinson et al. 2007; Ciutat et al. 2007; Schaller 2014; Zhang et al. 2014) and could induce 
potential toxic effects for aquatic organisms. Thus, based on this innovative experiment, we are currently investigating the anode dissolution impact on metal speciation in sediments and bioaccumulation in filter benthic organisms, according to different hydrodynamic conditions. The investigations are being performed in harbor under new cathodic protection by anodes as well as in mesocosms to corroborate these preliminary conclusions and assess the availability of the metal labile fraction to benthic organisms, which live in impacted sediments. More generally, these works highlight the mobility of $\mathrm{Al}$ in the marine environment.

Acknowledgments: This work was supported by the TALINE Project, funded by the SEPD-Port Boulogne-Calais and the Region Nord-Pas-de-Calais. The authors thank E. François, A. Mao, S. Le Glatin, D.Auger, andM. Robert for their technical assistance during sampling and chemical analysis. All the partners involved in the project are greatly appreciated, particularly P. Honoré for his administrative and technical commitment. Thanks to D. Reynolds for help with the English version of this paper, as well as the editor and reviewers for their helpful comments and suggestions for improvement.

\section{References}

Alberti, G., D’Agostino, G., Palazzo, G., Biesuz, R., Pesavento, M., 2005. Aluminium speciation in natural water by sorption on a complexing resin. Journal of Inorganic Biochemistry, 99(9): 1779-1787.

Atkinson, C. A., Jolley, D. F., Simpson, S. L. (2007). Effect of overlying water pH, dissolved oxygen, salinity and sediment disturbances on metal release and sequestration from metal contaminated marine sediments. Chemosphere, 69, 1428-1437.

Baker, T. J., Tyler, C. R., Galloway, T. S. (2014). Impacts of metal and metal oxide nanoparticles on marine organisms. Environmental Pollution, 186, 257-271.

Batley, G. E., Kirby, J. K., McLaughlin, M. J. (2013). Fate and risks of nanomaterials in aquatic and terrestrial environments. Accounts of Chemical Research, 46, 854-862.

Bird, P., Comber, S.D.W., Gardner, M.J., Ravenscroft, J.E., 1996. Zinc inputs to coastal waters from sacrificial anodes. Science of the Total Environment, 181(3): 257-264.

Boughriet, A., Proix, N., Billon, G., Recourt, P., Ouddane, B. (2007). Environmental impacts of heavy metal discharges from a smelter in Deûle-canal sediments (Northern France): concentration levels and chemical fractionation. Water Air Soil Pollution, 180, 83-95.

Breslin, C.B., Carroll, W.M., 1993. The activation of aluminium by activator elements. Corrosion Science, 35(1-4): 197-203.

Brown, J. et al., 1989. Ocean chemistry and deep-sea sediments, 134 pp.

Buck, C.S., Landing, W.M., Resing, J., 2013. Pacific Ocean aerosols: Deposition and solubility of iron, aluminum, and other trace elements. Marine Chemistry, 157(0): 117-130.

Buzier, R., Tusseau-Vuillemin, M.-H., dit Meriadec, C. M., Rousselot, O., Mouchel, J.-M. (2006). Trace metal speciation and fluxes within a major French wastewater treatment plant: impact of the successive treatments stages. Chemosphere, 65, 2419-2426. 
Buzier, R., Tusseau-Vuillemin, M.-H., Keirsbulck, M., Mouchel, J.-M. (2011). Inputs of total and labile trace metals from wastewater treatment plants effluents to the Seine River. Physics and Chemistry of the Earth, Parts A/B/C, 36, 500-505.

Caplat, C. et al., 2010. Comparative toxicities of aluminum and zinc from sacrificial anodes or from sulfate salt in sea urchin embryos and sperm. Ecotoxicology and Environmental Safety, 73(6): 1138-1143.

Caplat, C., Texier, H., Barillier, D., Lelievre, C., 2005. Heavy metals mobility in harbour contaminated sediments: The case of Port-en-Bessin. Marine Pollution Bulletin, 50(5): 504511.

Carroll, W.M., Breslin, C.B., 1992. Activation of aluminium in halide solutions containing 'activator ions'. Corrosion Science, 33(7): 1161-1177.

Chiffoleau, J.-F., Auger, D., Chartier, E. (1999). Fluxes of selected trace metals from the Seine estuary to the eastern English Channel during the period August 1994 to July 1995. Continental Shelf Research, 19, 2063-2082.

Chiffoleau, J.-F., Auger, D., Boutier, B., Rozuel, E., Truquet, I., 2003. Dosage de certains métaux dans les sédiments et les matières en suspension par absorption atomique.

Ciutat, A., Gerino, M., Boudou, A. (2007). Remobilization and bioavailability of cadmium from historically contaminated sediments: influence of bioturbation by tubificids. Ecotoxicology and Environmental Safety, 68, 108-117.

Cukrov, N., Frančišković-Bilinski, S., Hlača, B., Barišić, D., 2011. A recent history of metal accumulation in the sediments of Rijeka harbor, Adriatic Sea, Croatia. Marine Pollution Bulletin, 62(1): 154-167.

Danielsson, L.-G., Magnusson, B., Westerlund, S., Zhang, K., 1982. Trace metal determinations in estuarine waters by electrothermal atomic absorption spectrometry after extraction of dithiocarbamate complexes into freon. Analytica Chimica Acta, 144(0): 183-188.

Davison, W., Zhang, H., 1994. In situ speciation measurements of trace components in natural waters using thin-film gels. Nature, 367: 546-548.

de Souza, J. M., Menegário, A. A., de Araújo Júnior, M. A. G., Francioni, E. (2014).Measurements of labile $\mathrm{Cd}, \mathrm{Cu}, \mathrm{Ni}, \mathrm{Pb}$, and $\mathrm{Zn}$ levels at a northeastern Brazilian coastal area under the influence of oil production with diffusive gradients in thin films technique (DGT). Science of The Total Environment, 500-501, 325-331.

Duan, L., Song, J., Xu, Y., Li, X., \& Zhang, Y. (2010). The distribution, enrichment and source of potential harmful elements in surface sediments of Bohai Bay, North China. Journal of Hazardous Materials, 183, 155-164.

Ehrlich, A., 1988. Risk Assessment Guidelines Update. U.S. Environmental Protection Agency, Washington, D.C., EPA/600/D-88/264 (NTIS PB89133417).

Ellwood, M.J., Van den Berg, C.M.G., 2000. Zinc speciation in the Northeastern Atlantic Ocean. Marine Chemistry, 68(4): 295-306.

EPA, US. (2009). 'National Recommended Water Quality Criteria. United States Environmental Protection Agency', Office of Water, Office of Science and Technology, $21 \mathrm{pp}$.

Gabelle, C. et al., 2012. The impact of aluminium sacrificial anodes on the marine environment: A case study. Applied Geochemistry, 27(10): 2088-2095.

Guevara-Riba, A., Sahuquillo, A., Rubio, R., Rauret, G., 2004. Assessment of metal mobility in dredged harbour sediments from Barcelona, Spain. Science of The Total Environment, 321(13): 241-255.

Hédouin, L., Pringault, O., Bustamante, P., Fichez, R., Warnau, M. (2011). Validation of two tropical marine bivalves as bioindicators of mining contamination in the New Caledonia lagoon: field transplantation experiments. Water Research, 45, 483-496.

Idusuyi, N., Oluwole, O.O., 2012. Aluminium anode activation research : a review. International Journal of Science and Technology, 2(8): 561-565. 
Jelmert, A., van Leeuwen, J., 2000. Harming local species or preventing the transfer of exotics? Possible negative and positive effects of using zinc anodes for corrosion protection of ballast water tanks. Water Research, 34(6): 1937-1940.

Kim, T., Obata, H., Kondo, Y., Ogawa, H., Gamo, T. (2015). Distribution and speciation of dissolved zinc in the western North Pacific and its adjacent seas. Marine Chemistry, 173, 330-341.

Leleyter, L., Rousseau, C., Gil, O., Baraud, F., 2007. Répartition des métaux lourds dans les différentes fractions des sédiments marins : influence de la protection cathodique. Comptes Rendus Geoscience, 339(1): 31-39.

Mackin, J.E., Aller, R.C., 1984. Processes affecting the behavior of dissolved aluminum in estuarine waters. Marine Chemistry, 14(3): 213-232.

Mao, A., Mahaut, M.-L., Pineau, S., Barillier, D., Caplat, C., 2011. Assessment of sacrificial anode impact by aluminum accumulation in mussel Mytilus edulis: A large-scale laboratory test. Marine Pollution Bulletin, 62(12): 2707-2713.

Martínez-Santos,M., Probst, A., García-García, J., Ruiz-Romera, E. (2015). Influence of anthropogenic inputs and a high magnitude flood event on metal contamination pattern in surface bottom sediments from the Deba River urban catchment. Science of The Total Environment, 514, 10-25.

Michel, P., Boutier, B., Chiffoleau, J. F. (2000). Net fluxes of dissolved arsenic, cadmium, copper, zinc, nitrogen and phosphorus from the Gironde estuary (France): seasonal variations and trends. Estuarine, Coastal and Shelf Science, 51, 451-462.

Montero, N., Belzunce-Segarra, M.J., Gonzalez, J.L., Larreta, J., Franco, J., 2012. Evaluation of diffusive gradients in thin-films (DGTs) as a monitoring tool for the assessment of the chemical status of transitional waters within the Water Framework Directive. Marine Pollution Bulletin, 64(1): 31-39.

Mottin, E. et al., 2012. Effect of zinc sacrificial anode degradation on the defence system of the Pacific oyster, Crassostrea gigas: Chronic and acute exposures. Marine Pollution Bulletin, 64(9): 1911-1920.

Nadella, S. R., Tellis,M., Diamond, R., Smith, S., Bianchini, A., Wood, C. M. (2013). Toxicity of lead and zinc to developing mussel and sea urchin embryos: critical tissue residues and effects of dissolved organic matter and salinity. Comparative Biochemistry and Physiology Part C: Toxicology \& Pharmacology, 158, 72-83.

NF-EN-12473, 2014. Principes généraux de la protection cathodique en eau de mer

NF-EN-12495, 2000. Protection cathodique des structures en acier fixes en mer.

NF-EN-12496, NF-EN-ISO-13174, 2013. Anodes galvaniques pour la protection cathodique dans l'eau de mer et les boues salines \& Protection cathodique des installations portuaires.

Ohnemus,D. C., Lam, P. J. (2015). Cycling of lithogenic marine particles in the US GEOTRACES North Atlantic transect. Deep Sea Research Part II: Topical Studies in Oceanography, 116, 283-302.

OSPAR, 1997. Agreement 1197-15, Agreed ecotoxicological assessment criteria for trace metals, PCBs, PAHs, TBT and some organochlorine pesticides, OSPAR Convention, Brussels.

Paraskevas, D., Kellens, K., Dewulf, W., Duflou, J. R. (2015). Environmental modelling of aluminium recycling: a Life Cycle Assessment tool for sustainable metal management. Journal of Cleaner Production, 105, 357-370.

Paugam, L., Mao, A., Deborde, J., Goubert, E., Menard, N., Refait, P., Pineau, S. (2014). Comportement électrochimique des structures métalliques en condition de variations environnementales en zone estuarienne. Matériaux et Techniques, 101, 30-40.

Rousseau, C., Baraud, F., Leleyter, L., Gil, O., 2009. Cathodic protection by zinc sacrificial anodes: Impact on marine sediment metallic contamination. Journal of Hazardous Materials, 167(13): 953-958. 
Roy, A.H., 1968. Aluminium alloy anode and method of using same in cathodic protection. United States Patent Office, 3393: 138.

Saidman, S.B., Bessone, J.B., 1997. Activation of aluminium by indium ions in chloride solutions. Electrochimica Acta, 42(3): 413-420.

Santos, I. R., Silva-Filho, E. V., Schaefer, C. E. G. R.,

Albuquerque-Filho, M. R., Campos, L. S. (2005). Heavy metal contamination in coastal sediments and soils near the Brazilian Antarctic Station, King George Island. Marine Pollution Bulletin, 50, $185-194$.

Schaller, J. (2014). Bioturbation/bioirrigation by Chironomus plumosus as main factor controlling elemental remobilization from aquatic sediments? Chemosphere, 107, 336-343.

Shibli, S.M.A., Archana, S.R., Muhamed Ashraf, P., 2008. Development of nano cerium oxide incorporated aluminium alloy sacrificial anode for marine applications. Corrosion Science, 50(8): 2232-2238.

Shibli, S.M.A., Gireesh, V.S., 2005. Activation of aluminium alloy sacrificial anodes by selenium. Corrosion Science, 47(8): 2091-2097.

Skrabal, S. A., Lieseke, K. L., Kieber, R. J. (2006). Dissolved zinc and zinc-complexing ligands in an organic-rich estuary: benthic fluxes and comparison with copper speciation. Marine Chemistry, 100, 108-123.

Søndergaard, J., Bach, L., Gustavson, K. (2014). Measuring bioavailable metals using diffusive gradients in thin films (DGT) and transplanted seaweed (Fucus vesiculosus), blue mussels (Mytilus edulis) and sea snails (Littorina saxatilis) suspended from monitoring buoys near a former lead-zinc mine in West Greenland. Marine Pollution Bulletin, 78, 102-109.

Tang, C.W.-y. et al., 2008. The spatial and temporal distribution of heavy metals in sediments of Victoria Harbour, Hong Kong. Marine Pollution Bulletin, 57(6-12): 816-825.

Tessier, A., Gobeil, C., Laforte, L. (2014). Reaction rates, depositional history and sources of indium in sediments from Appalachian and Canadian Shield lakes. Geochimica et Cosmochimica Acta, 137, 48-63.

Thévenot, D. R., Moilleron, R., Lestel, L., Gromaire, M.-C., Rocher, V., Cambier, P., Bonté, P., Colin, J.-L., de Pontevès, C., Meybeck, M. (2007). Critical budget of metal sources and pathways in the Seine River basin (1994-2003) for Cd, Cr, Cu, Hg, Ni, Pb and Zn. Science of The Total Environment, 375, 180-203.

Tria, J., Butler, E. C. V., Haddad, P. R., Bowie, A. R. (2007). Determination of aluminium in natural water samples. Analytica Chimica Acta, 588, 153-165.

van den Berg, C.M.G., Boussemart, M., Yokoi, K., Prartono, T., Campos, M.L.A.M., 1994. Speciation of aluminium, chromium and titanium in the NW Mediterranean. Marine Chemistry, 45(4): 267-282.

Wagner, P. et al., 1996. Environmental fate of sacrificial zinc anodes and influence of a biofilm. International Biodeterioration \& Biodegradation, 37(3-4): 151-157.

Warnken, K.W., Zhang, H., Davison, W., 2007. Chapter 11 In situ monitoring and dynamic speciation measurements in solution using DGT. In: R. Greenwood, G.M., Vrana, B. (Eds.), Comprehensive Analytical Chemistry. Elsevier, pp. 251-278.

Zhang, H., Davison, W., 1995. Performance Characteristics of Diffusion Gradients in Thin Films for the in Situ Measurement of Trace Metals in Aqueous Solution. Analytical Chemistry, 67(19): 3391-3400.

Zhang, C., Yu, Z.-G., Zeng, G.-M., Jiang,M., Yang, Z.-Z., Cui, F., Zhu, M.-Y., Shen, L.-Q., Hu, L. (2014). Effects of sediment geochemical properties on heavy metal bioavailability. Environment International, 73, 270-281. 
Table 1. Anode weight evolution and electrochemical conditions during the130-day experimentation

\begin{tabular}{|c|c|c|c|c|c|}
\hline & \multicolumn{5}{|c|}{ Experimental tanks } \\
\hline & \multirow{2}{*}{$\frac{\mathrm{S} / \mathrm{A} \mathrm{T}}{1635.0}$} & \multicolumn{2}{|l|}{$100 \mathrm{~T}$} & \multicolumn{2}{|c|}{$200 / 100 \mathrm{~T}$} \\
\hline Initial anode weight (g) & & 1739.0 & 1702.0 & 1603.0 & 1691.0 \\
\hline Final anode weight (g) & 1549.0 & 1625.5 & 1559.5 & 1397.5 & 1511.5 \\
\hline Anode weight loss (g) & 86.0 & 113.5 & 142.5 & 205.5 & 179.5 \\
\hline Anode dissolution rate $\left(\mathrm{mg} \mathrm{cm}^{-2} \mathrm{~d}^{-1}\right)$ & 1.1 & 1.4 & 1.7 & 2.5 & 2.2 \\
\hline Current discharge (mA) & $70 \pm 20$ & \multicolumn{2}{|c|}{$100 \pm 10$} & \multicolumn{2}{|c|}{$200 \pm 20$ (60 days) $100 \pm 10$ (70 days) } \\
\hline Potential (mV/ECS) & $-1050 \pm 50$ & \multicolumn{2}{|c|}{$-1020 \pm 120$} & \multicolumn{2}{|c|}{$-1050 \pm 50$} \\
\hline
\end{tabular}


Table 2. Average concentrations ( $\mathrm{n}=2$ to 4 ) of $\mathrm{Al}, \mathrm{Zn}$ and $\mathrm{In}$ in liquid and solid fractions of the corrosion product layers collected on anode surfaces and in the sludge settled at the bottom of tanks after 130 days of experimentation.

\begin{tabular}{|c|c|c|c|}
\hline Tank & $\mathrm{Al}$ & $\mathrm{Zn}$ & In \\
\hline & \multicolumn{3}{|c|}{ Corrosion product layers (solid fraction) } \\
\hline & $\mathrm{mg} \mathrm{g}^{-1}$ & $\mathrm{mg} \mathrm{g}^{-1}$ & $\mu \mathrm{g} \mathrm{g}^{-1}$ \\
\hline $\mathrm{S} / \mathrm{AT}$ & $159.3 \pm 1.9$ & $0.3 \pm 0.1$ & $50.4 \pm 8.2$ \\
\hline $100 \mathrm{~T}$ & $154.7 \pm 10.0$ & $0.4 \pm 0.1$ & $41.3 \pm 10.1$ \\
\hline \multirow[t]{3}{*}{$200 / 100 \mathrm{~T}$} & $155.6 \pm 1.4$ & $0.4 \pm 0.1$ & $74.8 \pm 4.7$ \\
\hline & \multicolumn{3}{|c|}{$\begin{array}{l}\text { Liquid fraction of the corrosion product layers } \\
\text { (interstitial waters) }\end{array}$} \\
\hline & $\mathrm{mg} \mathrm{L}^{-1}$ & $\mathrm{mg} \mathrm{L}^{-1}$ & $\mu \mathrm{g} \mathrm{L}^{-1}$ \\
\hline $\mathrm{S} / \mathrm{AT}$ & $56.5 \pm 0.0$ & $9.2 \pm 0.4$ & $<$ d.l. \\
\hline $100 \mathrm{~T}$ & $446.4 \pm 147.2$ & $23.9 \pm 0.7$ & $<$ d.1. \\
\hline \multirow[t]{3}{*}{$200 / 100 \mathrm{~T}$} & $127.3 \pm 30.9$ & $13.7 \pm 1.0$ & $<$ d.l. \\
\hline & \multicolumn{3}{|c|}{ Tank sediments (solid fraction) } \\
\hline & $\mathrm{mg} \mathrm{g}^{-1}$ & $\mathrm{mg} \mathrm{g}^{-1}$ & $\mu g^{-1}$ \\
\hline $\mathrm{RT}$ & $7.8 \pm 0.3$ & $0.7 \pm 0.0$ & $<$ d.l. \\
\hline S/A T & $82.2 \pm 1.4$ & $1.0 \pm 0.3$ & $17.2 \pm 4.9$ \\
\hline $100 \mathrm{~T}$ & $115.7 \pm 8.2$ & $0.5 \pm 0.2$ & $27.9 \pm 5.0$ \\
\hline \multirow[t]{3}{*}{$200 / 100 \mathrm{~T}$} & $106.7 \pm 9.0$ & $0.7 \pm 0.1$ & $28.7 \pm 10.0$ \\
\hline & \multicolumn{3}{|c|}{ Interstitial waters of tank sediments } \\
\hline & $\mathrm{mg} \mathrm{L}^{-1}$ & $\mathrm{mg} \mathrm{L}^{-1}$ & $\mu \mathrm{g} \mathrm{L}^{-1}$ \\
\hline $\mathrm{R} \mathrm{T}$ & $<$ d.l. & $0.2 \pm 0.1$ & $<$ d.l. \\
\hline S/A T & $0.4 \pm 0.2$ & $3.5 \pm 2.6$ & $<$ d.1. \\
\hline $100 \mathrm{~T}$ & $600.9 \pm 54.3$ & $45.0 \pm 21.9$ & $<$ d.1. \\
\hline $200 / 100 \mathrm{~T}$ & $793.2 \pm 103.1$ & $<\mathrm{d} .1$ & $58.7 \pm 4.0$ \\
\hline
\end{tabular}

Standard deviation is in italics. d.l. detection limit, $0.5 \mu \mathrm{g} \mathrm{g}{ }^{-1}$ and $5 \mu \mathrm{g} \mathrm{L}^{-1}$ 
Table 3. Theoretical inputs ( $\left.\mu \mathrm{g} \mathrm{cm}^{-2} \mathrm{day}^{-1}\right)$ and total concentrations $\left(\mu \mathrm{g} \mathrm{L} \mathrm{L}^{-1}\right)$ of metals released from galvanic anode alloy to the aquatic compartment of the experimental tanks

\begin{tabular}{lllllllll}
\hline & Experimental Tank & $\mathrm{Al}$ & $\mathrm{Zn}$ & $\mathrm{In}$ & $\mathrm{Cu}$ & $\mathrm{Fe}$ & $\mathrm{Si}$ & $\mathrm{Mn}$ \\
\hline Theoretical inputs $\left(\mu \mathrm{g} \mathrm{cm}^{-2} \mathrm{day}^{-1}\right.$ ) & S/A T & 979 & 68.3 & 0.3 & 0.1 & 0.9 & 1.1 & 0.1 \\
& $100 \mathrm{~T}$ & 1292 & 90.1 & 0.4 & 0.1 & 1.2 & 1.4 & 0.1 \\
& & 1623 & 113.1 & 0.5 & 0.1 & 1.6 & 1.7 & 0.2 \\
& $200 / 100 \mathrm{~T}$ & 2340 & 163.1 & 0.8 & 0.2 & 2.3 & 2.5 & 0.3 \\
Theoretical total concentrations $\left(\mu \mathrm{g} \mathrm{L}^{-1}\right)$ & & 2044 & 142.5 & 0.7 & 0.1 & 2.0 & 2.2 & 0.2 \\
& S/A T & 214 & 14.93 & 0.07 & 0.01 & 0.21 & 0.23 & 0.02 \\
& $100 \mathrm{~T}$ & 283 & 19.70 & 0.09 & 0.02 & 0.27 & 0.30 & 0.03 \\
& & 355 & 24.74 & 0.11 & 0.02 & 0.34 & 0.38 & 0.04 \\
& $200 / 100 \mathrm{~T}$ & 512 & 35.68 & 0.16 & 0.03 & 0.49 & 0.55 & 0.05 \\
& & 447 & 31.16 & 0.14 & 0.03 & 0.43 & 0.48 & 0.05 \\
\hline
\end{tabular}

Values have been calculated according to the maximal abundance of each metal in the anode alloy (Zn $6.5 \%$; In $0.03 \%$; Fe $0.09 \%$; Si $0.1 \%$; Cu $0.006 \%$; Mn $0.01 \%$; Al 93.26 \%), surface anode $\left(630 \mathrm{~cm}^{2}\right)$ and the total weight loss of anodes after 130 days of cathodic protection (Table 1) with a water renewal at $120 \mathrm{~L} \mathrm{~h}^{-1}$. NB: the analytical detection limit was $5 \mu \mathrm{g} \mathrm{L}^{-1}$ for total concentrations of metals in the tank waters 

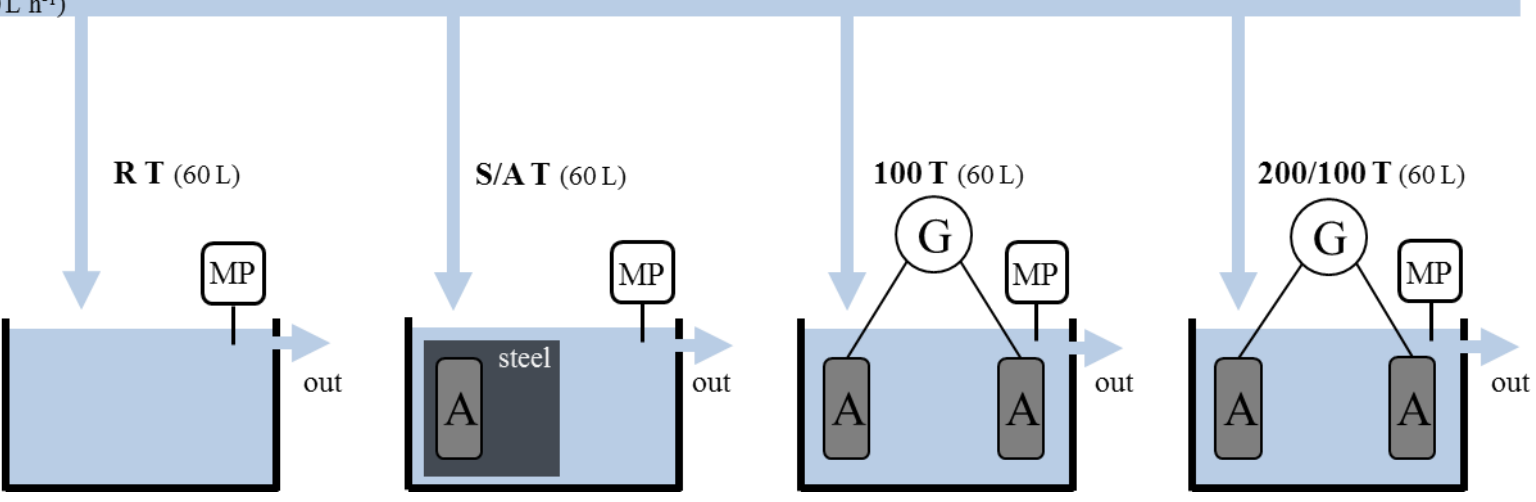

Figure 1. Experimental unit setup. G: Galvanostat; MP: multi-parametric probe (T, pH, S, $\left.\mathrm{O}_{2}\right)$; $A$ : Anode Bera15 BAC $^{\circledR}$; RT: Reference Tank without anode; S/A T: Tank with Steel sample coupled to galvanic Anode; 100T or 200/100T: Tank with two galvanic anodes coupled to galvanostat at 100 or $200 \mathrm{~mA}$. 


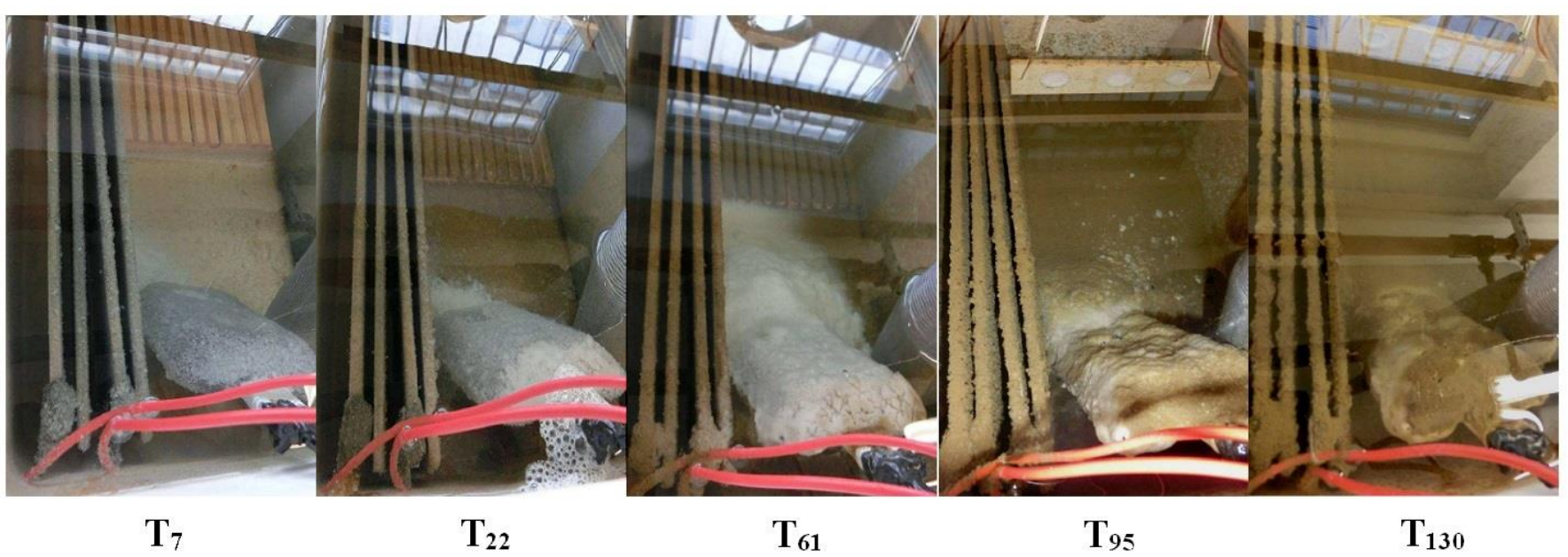

Figure 2. Dissolution of galvanic anode in the experimental tank containing steel/anode combination (S/A T) and formation of corrosion products (white layer) during the 130-day experiment. 

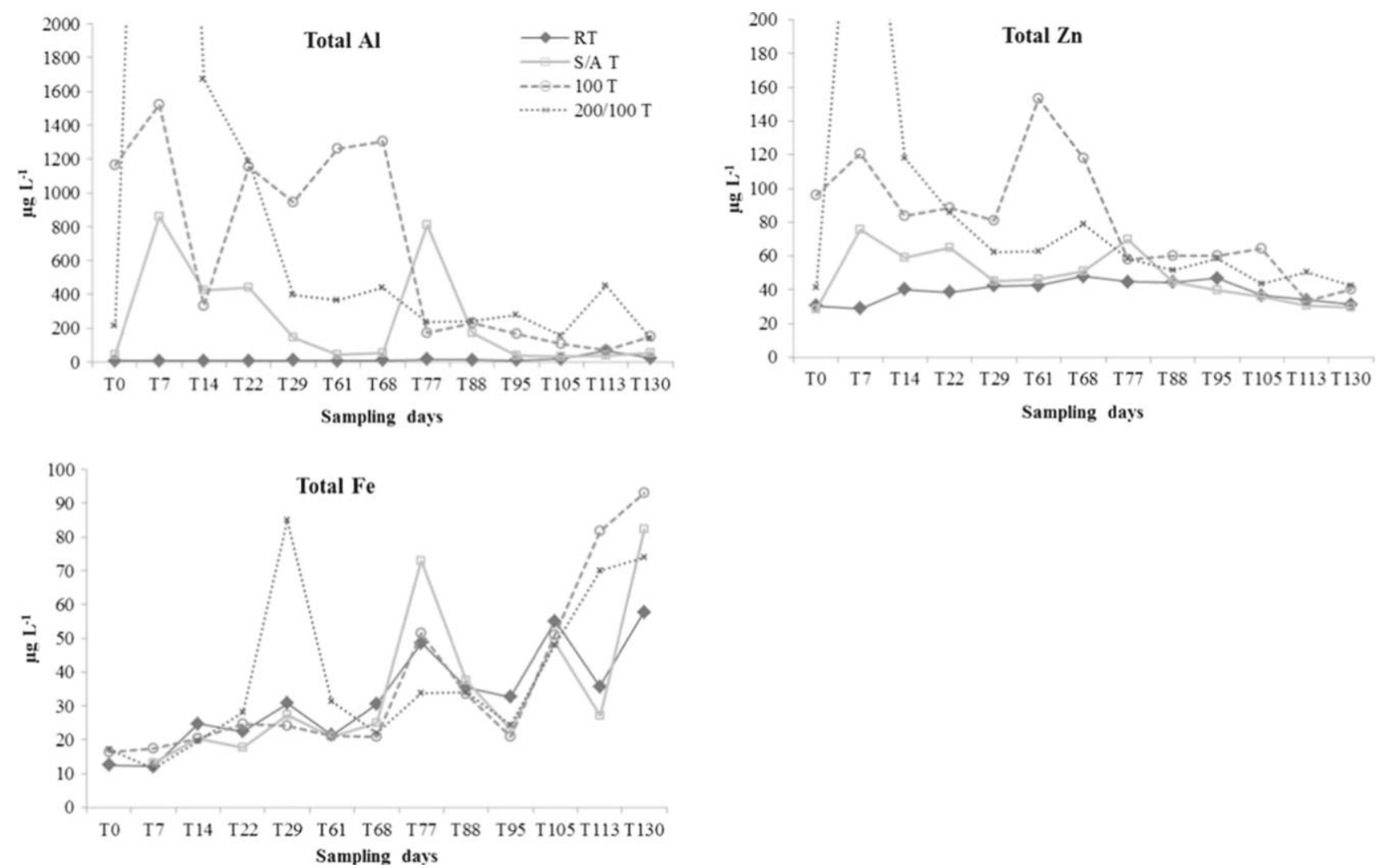

Figure 3. Concentrations of total $\mathrm{Al}, \mathrm{Fe}$, and $\mathrm{Zn}\left(\mu \mathrm{g} \mathrm{L}^{-1}\right)$ measured in seawaters of experimental tanks (RT, S/A T, $100 \mathrm{~T}$, and 200/100 T) during the 130-day experiment. 

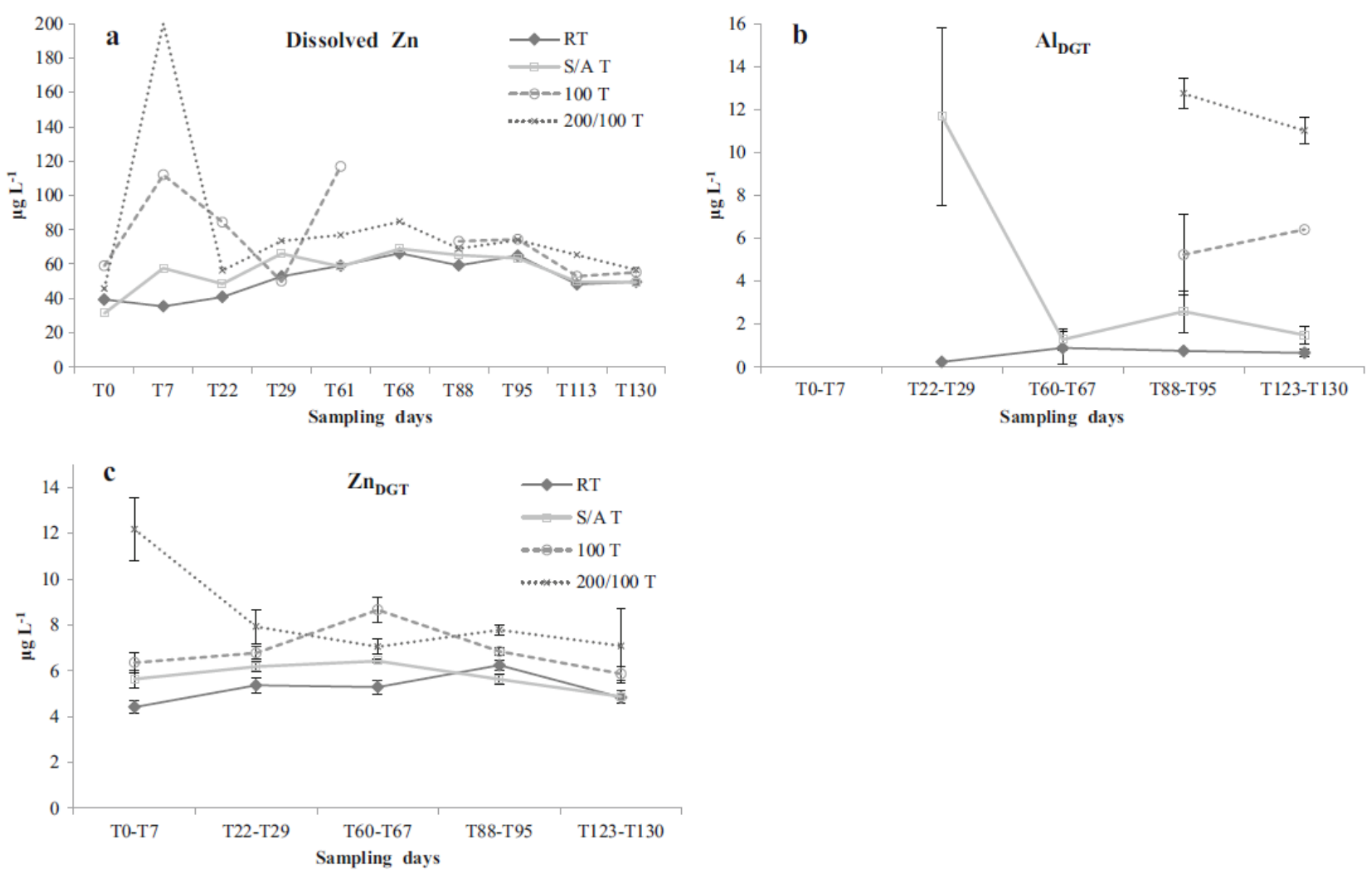

Figure 4. $\mathrm{Al}$ and $\mathrm{Zn}$ concentrations in the dissolved fraction during the 130-day experiment: a dissolved $\mathrm{Zn}$ concentrations ( $\mu \mathrm{g} \mathrm{\textrm {L } ^ { - 1 }}$, filtered at $0.45 \mu \mathrm{m}$ ) measured in seawaters of experimental tanks (RT, S/A T, 100 T, and 200/100 T); b-c labile Al and Zn concentrations measured using DGT method (7 days immersed) in seawaters of experimental tanks (RT, S/A T, 100 T, and 200/ 100 T), the data are expressed as the mean \pm standard error of the mean $(n=3)$. 
